\title{
IbM MEMBANGUN “DESA CERMAT” MELALUI BIMBINGAN BELAJAR DALAM MENINGKATKAN HASIL BELAJAR MATEMATIKA SISWA
}

\author{
Vera Dewi Susanti ${ }^{1)}$, Swasti Maharani ${ }^{2)}$ \\ ${ }^{1)}$ FPMIPA, IKIP PGRI Madiun \\ email: veradewisusanti@yahoo.com \\ ${ }^{2)}$ FPMIPA, IKIP PGRI Madiun \\ email: swastimaharani@yahoo.com
}

\begin{abstract}
IbM is motivated by the many children who come from poor families who can not follow the lessons, after school activities so that they spend a lot of play. In addition, many students and graduates who do not have the activity/work due to lack of jobs. Therefore, in this IbM the researchers intend to make les. In this IbM focused guidance for poor children and will involve students and graduates IKIP PGRI Madiun. Partner is the chief village IbM Watuompak and Bangunrejo. IbM aims to improve student learning outcomes through tutoring mathematics as a means to build a "Cermat" village in the village Rejosari Kebonsari Madiun and students or graduates to become active through tutoring. The stages of this research starts from the preparation phase support equipment guidance, the next stage of implementation / field, program evaluation by a team of researchers and partners and the final completion of the final report.
\end{abstract}

Keywords: Tutoring , Math Learning Outcomes

\section{PENDAHULUAN}

Pendidikan merupakan salah satu faktor yang tak dapat dipisahkan dari kehidupan seseorang baik dalam keluarga, masyarakat dan bangsa. Negara berkembang seperti Indonesia sangat dipengaruhi oleh perkembangan dunia pendidikan. Kesuksesan dalam pembangunan tidak hanya dipengaruhi oleh kemampuan dibidang ekonomi, tetapi juga kualitas sumber daya yang menjalankan proses pembangunan tersebut. Pendidikan bertujuan untuk mencerdaskan kehidupan bangsa juga sekaligus meningkatkan harkat dan martabat manusia. Melalui pendidikan itulah diharapkan dapat tercapai peningkatan kehidupan manusia ke arah yang sempurna.

Sekolah merupakan salah satu lembaga yang menjujung tinggi pendidikan. Pengetahuan dan segala wawasan dapat ditemukan di sekolah. Banyak sekolah yang berdiri di Indonesia baik sekolah negeri maupun sekolah swasta. Begitu juga sekolah yang terdapat di desa Rejosari kecamatan Kebonsari kabupaten Madiun, di desa ini terdapat beberapa sekolah diantaranya 4 PAUD (pendidikan sekolah non formal) yaitu PAUD Al-Karimah, PAUD Tunas Bangsa, PAUD bahrul ulum dan PAUD Tunas Cendekia, 5 sekolah dasar yaitu MIN Rejosari, MI Bahrul Ulum, SD Negeri 1 Rejosari, MI Salafiyah Kembangsawit dan SD Negeri 2 Rejosari, 2 sekolah menengah pertama yaitu MTsN Rejosari dan SMP IT, 1 sekolah menengah atas yaitu MAN Rejosari.

Dilihat dari segi pendidikan yang cukup lengkap di desa Rejosari mulai dari sekolah nonformal sampai sekolah menengah atas, tentu sumber daya manusia yang dihasilkan berkualitas. Namun pada kenyataannya, siswasiswi yang berasal dari desa Rejosari terutama dusun Bangunrejo dan dusun Watuompak sumber daya manusia belum maksimal. Hal ini dikarenakan jam pelajaran di sekolah semakin padat. Di sekolah pelajaran dimulai jam 07.00 sampai jam 15.00, sehingga dalam pelaksanaannya siswa dituntut memahami mata pelajaran yang sangat banyak dan beragam. Bagi siswa yang cerdas mungkin bisa mengikuti mata pelajaran yang diberikan oleh guru, tetapi bagi siswa yang daya berfikirnya kurang akan kesulitan memahami dan menyerap ilmu yang diberikan oleh guru.

Di sekolah mata pelajaran matematika merupakan salah satu mata pelajaran diberikan guru kepada semua siswa. Matematika sangat berperan dalam kehidupan sehari-hari, dari halhal yang sangat sederhana sampai pada hal-hal yang sangat kompleks. Sementara itu, pada pemikiran ilmu pengetahuan dan teknologi, matematika merupakan salah satu ilmu dasar bagi ilmu-ilmu lainnya, sehingga dalam perkembangan pendidikan, matematika dijadikan sebagai barometer untuk mengukur 
tingkat kecerdasan dan daya pikir anak. Selain itu, matematika merupakan ilmu universal yang mendasari perkembangan teknologi modern, mempunyai peran penting dalam berbagai disiplin ilmu dan memajukan daya pikir manusia, serta berperan sangat penting dalam persiapan untuk memberi bekal agar kita dapat berfungsi secara efektif dalam zaman teknologi.

Dalam mempelajari matematika, matematika sangat terkait dengan berpikir matematika yaitu berpikir merumuskan suatu himpunan yang sudah diketahui. Oleh karena itu dalam mempelajari matematika jika konsep A mendasari atau merupakan prasyarat bagi konsep B, maka konsep B tidak dapat dikuasai sebelum konsep A dipahami terlebih dahulu. Hal ini juga diungkapkan Schoenfield (Hamzah B. Uno, 2007:130) mendefinisikan, bahwa belajar matematika berkaitan dengan apa dan bagaimana menggunakannya dalam membuat keputusan untuk memecahkan masalah. Matematika dilibatkan pengamatan, penyelelidikan dan keterkaitannya dengan fenomena fisik dan sosial. Berkaitan dengan hal ini, maka belajar matematika merupakan suatu kegiatan yang berkenaan dengan penyelesaian himpunan-himpunan dari unsur matematika yang sederhana dan merupakan himpunanhimpunan baru, yang selanjutnya membentuk himpunan yang lebih rumit. Demikian seterusnya, sehingga dalam belajar matematika harus dilakukan secara hierarkis. Begitu terkonsepnya mempelajari matematika, kadang siswa belum paham dengan konsep A sudah dituntut untuk mempelajari konsep B. Sehingga siswa merasa kesulitan dalam mempelajari matematika. Ini menjadikan matematika sebagai "momok" dari semua pelajaran. Dalam mengatasi masalah tersebut perlu ada jam tambahan di luar sekolah untuk mengatasi kesulitan dalam mempelajari matematika. Bimbingan belajar merupakan salah satu alternatifnya, namun dalam bimbingan belajar sekarang ini, bimbingan belajar dibuat sebagai bisnis dalam mencari uang. Tujuan utama dengan mengedepankan membangun generasi penerus bangsa menjadi cerdas sering dikesampingkan. Sehingga hanya anak-anak yang tergolong mampu saja yang bisa mengikuti bimbingan belajar. Sangat disayangkan apabila anak-anak cerdas yang kurang mampu hanya bisa mengandalkan materi yang diterimanya di sekolah, padahal bila anak-anak tersebut mendapatkan pengetahuan selain dari sekolah, wawasan anak-anak tersebut bisa berkembang menjadi luas.
Seperti yang diungkapkan oleh bapak Khoiruddin kepala dusun Bangunrejo, sebagian besar pekerjaan penduduk di dusun Bangunrejo adalah buruh tani. Sehingga siswa-siswi di dusun Bangunrejo tersebut setelah pulang dari sekolah kegiatan mereka hanya dihabiskan untuk bermain. Seharusnya akan lebih bermanfaat jika waktu luang mereka digunakan untuk bimbingan belajar. Tapi untuk mengikuti bimbingan belajar perlu dana tambahan, sedangkan penghasilan sebagai buruh tani hanya cukup untuk keperluan sehari-hari. Tidak berbeda dengan kondisi di Watuompak, menurut keterangan dari kepala dusun Watuompak anakanak yang berasal dari keluarga yang kurang mampu, banyak siswa-siswi tidak mengikuti bimbingan belajar dengan alasan faktor biaya dari mengikuti bimbingan belajar yang lumayan mahal. Selain itu terdapat banyak lulusan sarjana yang berasal dari desa Rejosari dan dusun Bangunrejo dan dusun Watuompak yang sulit mencari pekerjaan, sehingga setelah lulus mereka tidak mempunyai kegiatan produktif.

Berdasarkan permasalahan yang diungkapkan diatas, peneliti akan mengusulkan membentuk bimbingan belajar untuk siswasiswi yang kurang mampu tersebut. Dengan adanya bimbingan belajar ini, selain pengetahuan siswa-siswi di desa Rejosari khususnya dusun Bangunrejo dan dusun Watuompak akan menjadi luas juga mahasiswa dan lulusan sarjana akan mendapatkan pekerjaan.

Kegiatan IbM ini bertujuan meningkatkan hasil belajar matematika siswa melalui bimbingan belajar sebagai sarana membangun desa "Cermat" di desa Rejosari Kebonsari Madiun dan mengaktifkan kegiatan mahasiswamahasiswa yang berdomisili di desa Rejosari beserta lulusan sarjana yang masih belum mendapatkan pekerjaan.

Sasaran kegiatan IbM ditujukan kepada siswa-siswi di Desa Rejosari yang termasuk keluarga kurang mampu baik siswa-siswi yang berasal dari SD sampai MA/ SMA serta mahasiswa dan lulusan IKIP PGRI Madiun yang berdomisili di Desa Rejosari.

Kegiatan IbM ini diharapkan menghasilkan luaran berupa ; (1) bimbingan belajar yang dapat menampung anak-anak dari keluarga yang tidak mampu, (2) anak-anak di Desa Rejosari yang cerdas yang bisa memahami berbagai persoalan matematika, (3) Kegiatan mahasiswa/ lulusan sarjana yang belum mendapatkan pekerjaan menjadi aktif dengan mengajar di bimbingan belajar. 
2. METODE PELAKSANAAN PROGRAM

Adapun tahap-tahap IbM ini adalah

a. Persiapan

Adapun kegiatan-kegiatan yang akan

dilakukan pada tahap persiapan yaitu:

- Pembuatan proposal

- Survei tempat pelaksanaan kegiatan dan penyelesaian administrasi perijinan tempat atau lokasi pengabdian masyarakat.

- Sosialisasi kepada mahasiswa dan lulusan sarjana.

- Mempersiapan perlengkapan penunjang bimbingan belajar.

- Pembuatan modul matematika.

- Penggandaan modul sesuai dengan jumlah peserta.

b. Pelaksanaan kegiatan

Dalam pelaksanaan bimbingan belajar ini yang menjadi pengajar adalah mahasiswa-mahasiswa IKIP PGRI Madiun yang berdomisili di desa Rejosari dan lulusan sarjana yang belum mendapatkan pekerjaan khususnya lulusan sarjana pendidikan matematika. Hal ini dimaksudkan agar mahasiswa IKIP PGRI Madiun sebagai calon guru mempunyai pengalaman dalam mengajar serta ilmu yang didapat selama perkuliahan dapat langsung tersalurkan dan lulusan sarjana bisa mendapatkan pekerjaan. Pada kegiatan IbM ini, siswa yang mengikuti bimbingan belajar tetap dipungut biaya tetapi tidak sebesar biaya bimbingan belajar komersil pada umumnya. Hal ini dimaksudkan biaya tersebut akan digunakan keperluan administrasi setelah IbM selesai dengan harapan walaupun IbM berakhir, tetapi bimbingan tersebut masih tetap berjalan.

Sasaran kegiatan IbM ditujukan kepada siswa-siswi di Desa Rejosari yang termasuk kedalam golongan keluarga kurang mampu baik siswa-siswi yang berasal dari sekolah dasar sampai siswa-siswi dari madrasah aliyah atau setara dengan sekolah menengah atas. Hal ini dimaksudkan agar setelah kegiatan IbM ini selesai bimbingan belajar dapat terus berjalan dengan solusi siswa-siswi dari sekolah menengah atas dapat mengajari matematika siswa-siswi dari sekolah menengah pertama atau madrasah tsanawiyah, begitu juga siswa-siswa yang berasal dari SMP atau MTs dapat mengajari siswa-siswi dari sekolah dasar atau MI. Sedangkan siswa-siswi dari sekolah menengah atas dapat meminta bantuan dari mahasiswa IKIP PGRI Madiun untuk mengajari matematika.

c. Evaluasi

Evalusi ini bertujuan untuk melihat perkembangan program yang dilaksanakan, untuk mengetahui kendala yang ada dan cara menanganinya sehingga program pengabdian yang dilakukan benar-benar efektif dan maksimal. Evaluasi yang terakhir yaitu berupa pemberian ujian kepada anakanak yang mengikuti bimbingan. Hal ini dimaksudkan untuk mengetahui perkembangan pengetahuan mereka dibanding sebelum mengikuti bimbingan belajar. Bagi mereka yang mendapat nilai yang baik akan diberi penghargaan agar anak termotivasi belajar dengan baik.

d. Pembuatan Laporan

- Pembuatan Laporan Awal

Pembuatan laporan awal disesuaikan dengan hasil yang telah dicapai selama melakukan bimbingan belajar anak desa Rejosari.

- Revisi Laporan

- Revisi laporan dilakukan apabila terjadi kesalahan pada pembuatan laporan awal.

- Pembuatan Laporan Akhir

Pembuatan laporan akhir dilakukan setelah melakukan revisi laporan agar dalam penyusunan laporan akhir diperoleh hasil yang lebih baik.

\section{HASIL DAN PEMBAHASAN}

Kegiatan IbM ini diawali dengan sosialisasi terhadap mahasiswa maupun lulusan IKIP PGRI Madiun yang berjurusan matematika yang berdomisili di desa Rejosari terutama dusun Bangunrejo dan dusun Watu Ompak. Sosialisasi ini dilakukan berfungsi sebagai pemberitahuan kepada mereka akan dilaksanakannya IbM yang berjudul "Membangun "Desa Cermat" Melalui Bimbingan Belajar Dalam Meningkatkan Hasil Belajar Matematika Siswa di Desa Rejosari, Kebonsari, Madiun". Dari sosialisasi mereka mau meluangkan waktu dan tenaga untuk mendukung kelancaran dalam pelaksanaan IbM yang akan dilaksanakan.

Setelah sosialisasi dilakukan tahap selanjutnya adalah persiapan perlengkapan penunjang kegiatan IbM. Perlengkapan yang disiapkan selama IbM adalah sebagai berikut:
1. Papan Tulis
2. Meja Lipat
3. Perlengkapan Alat Tulis
4. Pembuatan dan penggandaan modul 


\section{Pembuatan Banner}

Setelah perlengkapan penunjang sudah siap, tahap selanjutnya adalah mengundang anak-anak atau para siswa untuk datang ke lokasi bimbingan belajar. Dalam pelaksanaan IbM ini kegiatan bimbingan belajar diterapkan berbeda dengan bimbingan belajar pada umumnya. Bimbingan belajar yang diterapkan menggunakan metode/model pembelajaran yang telah dipelajari di perkuliahan. Bimbingan belajar yang akan direncanakan pada program pengabdian masyarakat sebanyak 3 kali pertemuan.

Pada pertemuan pertama dan kedua yang sudah dilakukan, siswa siswi bimbingan belajar difokuskan kepada siswa-siswi yang berasal dari SD/MI mengingat akan dilaksanakannya ujian nasional. Materi yang telah disampaikan kepada siswa-siswi SD/MI. Berhubung siswa-siswi dari SMP dan SMA sedikit, siswa-siswi bimbingan belajar digabung dalam satu kali pertemuan. Materi yang telah diajarkan kepada siswa-siswi SMP dan SMA.

\section{KESIMPULAN}

Kesimpulan yang didapat selama kegiatan IbM ini adalah

a. Sebanyak $85 \%$ dari siswa-siswi bimbingan belajar lebih memahami dan menguasai materi matematika serta siswa-siswi tersebut dapat mengaplikasikan soal-soal matematika dalam kehidupan sehari-hari sehingga materi tersebut mudah dipahami.

b. Kegiatan mahasiswa-mahasiswa dan lulusan sarjana yang belum mendapatkan pekerjaan menjadi aktif dengan mengajar di bimbingan belajar.

\section{REFERENSI}

Hamzah B. Uno, 2007. Model Pembelajaran Menentukan Proses Belajar Mengajar yang Kreatif dan Efektif. Jakarta : PT Bumi Aksara. 